Human rights education in Japan: an historical account, characteristics and suggestions for a better-balanced approach

Cambridge Journal of Education

Sachiko Takeda

The Business School, Bournemouth University, Bournemouth, UK

EB401 Executive Business Centre

Bournemouth University

89 Holdenhurst Road

Bournemouth BH8 8EB

United Kingdom

E-mail: stakeda@ bournemouth.ac.uk

Telephone: $(+44)(0) 1202961865$ 


\title{
Human rights education in Japan: an historical account, characteristics and suggestions for a better-balanced approach
}

\begin{abstract}
Although human rights are often expressed as universal tenets, the concept was conceived in a particular socio-political and historical context.

Conceptualisations and practice of human rights vary across societies, and face numerous challenges. After providing an historical account of the conceptualisation of human rights in Japanese society, this paper examines human rights education in Japan, focusing on implementation of the United Nations Decade for Human Rights Education. Whilst the Decade's Action Plan advocates a comprehensive approach, Japanese human rights education focuses far less attention on imparting knowledge and developing learners' attitudes, placing strong emphasis on aspects of responsibility and harmonious human relations understood in the historical context of Japanese moral education. Pedagogical proposals are made to promote a comprehensive approach, including focus on the role of empowering learners, enabling them to protect themselves by invoking human rights.
\end{abstract}

Keywords: human rights; citizenship education; learner empowerment; Japan; United Nations Decade for Human Rights Education

\section{Introduction}

The Plan of Action for the United Nations Decade for Human Rights Education (UN Action Plan) (United Nations, 1994) states that human rights education should be implemented through 'the imparting of knowledge and skills and the moulding of attitudes' within 'a comprehensive approach'. It states that the Decade for Human Rights Education (UN Decade: 1995-2004) 'shall be based upon the provision of the international human rights instruments'. The establishment of the concept and instruments of human rights as inalienable rights of every human being is the fruit of centuries of efforts and struggles, for the effective means to protect human dignity, mainly in societies where the concept was born and refined. It is therefore understandable that human rights education, as advocated by the UN Decade, is based on the experiences of those societies.

As they do not share the same context, societies have different approaches to human rights education, with varying historical and sociological development, cultures, and traditions that pose disparate issues and challenges. Examining human 
rights education in Japan provides one such example. It reveals how human rights education is shaped in a society where the idea of human rights is a relatively new concept, introduced from the West in the late $19^{\text {th }}$ century.

Cohrs, Maes, Moschner, and Kielmann (2007) argue that human rights researchers identify 'different aspects or dimensions of human rights orientations'. They provide a list of foci, including attitudinal dimensions, knowledge and importance, feelings of responsibility, commitment, willingness to engage in human rights behaviour, and self-reported behaviour. All of these dimensions need to be addressed in a balanced manner in human rights education since they are interrelated. Cohrs et al. (2007) demonstrate that being able to spontaneously recite human rights stipulated by the UN Universal Declaration of Human Rights correlates with high participation in human rights promotion, such as taking part in a demonstration within the previous five years, confirming correlation between human rights knowledge and human rights behaviour.

The discussion in this paper suggests that there is an imbalance in the dimensions stressed in Japanese human rights education; stronger emphasis is placed on certain dimensions. The aim of this study is to examine these features of Japanese human rights education and the conceptualisations of human rights amongst the Japanese people, with consideration of the historical and sociological development of the concept. To this end, this paper first provides an account of the development of the concept of human rights, and how this concept, having originated in the West, was introduced into Japanese society. The validity of introducing human rights into Japanese society is also discussed briefly. The paper then examines the Japanese government's guidelines on human rights education, produced in response to the establishment of the UN Decade. These guidelines emphasise specific dimensions of 
human rights. This is followed by an investigation into the way human rights are taught in Japanese schools, pointing out that Japanese human rights education places more emphasis on some dimensions over others. This leads to a pedagogical suggestion as to how Japanese human rights education should change if it is to contribute to the empowerment of tomorrow's citizens, so that they can use human rights as an instrument to protect themselves when rights are violated.

\section{Historical framework}

When considering the development of the concept of human rights, the Magna Carta of 1215 is often cited as the first human rights document. However, rights of the medieval period were far removed from contemporary conceptualisations, and applied only to aristocracies, feudal lords, and the Church. Similar qualifications apply to the Habeas Corpus Act of 1679 and the English Bill of Rights of 1689. Even the French and American Declarations, widely considered to be the origins of contemporary human rights, did not establish inalienable rights for every human being. The United States Declaration of Independence of 1776 declared 'that all men are created equal; that they are endowed by their Creator with certain unalienable rights'. Nevertheless, these inalienable rights did not apply to black slaves, Native Americans, or women. The French Declaration of the Rights of Man and Citizen of 1789 decreed 'Men are born and remain free and equal in rights' but excluded the poor, women, non-whites, religious minorities, and other minorities such as homosexuals and disabled people. The fact that large-scale, systemic violations of human rights were committed against many peoples after these two declarations were written indicates clearly that what the two declarations called 'men' did not include non-whites of non-European origins. 
The establishment of inalienable rights for every human being first appeared in the United Nations Universal Declaration of Human Rights of 1948, which included all people 'without distinction of any kind, such as race, colour, sex, language, religion, political or other opinion, national or social origin, property, birth or other status'. Despite its universality, the Universal Declaration followed the phrasing of the French Declaration closely, "substituting "human" for the more ambiguous "man" throughout' (Hunt, 1996, p. 3). This indicates that the concept of human rights, as we currently understand, is of Western origin. In fact, the Universal Declaration was drafted primarily by representatives of the United States and Western Europe, and reflects liberal traditions. The rest of the world was not offered much opportunity to influence the contents of the text. This is not surprising considering that only eleven African and Asian countries were among the founding UN members, with seven more joining over the following ten years (An-Na'im, 1990).

Since then, an increasing number of non-Western states have joined the UN. Accordingly, the concept and norms of human rights, as contained in the Universal Declaration and other UN human rights instruments, have been formally accepted by the governments of countries with different social and cultural traditions. When discussing human rights education, it is crucial to recognise this process and that societies have different historical frameworks with regard to human rights as a concept. Consequently, the concept poses unique challenges to any society, resulting in societies having varying approaches to human rights education.

\section{Introduction of the human rights concept into Japanese society}

For two and a half centuries until the latter half of the $20^{\text {th }}$ century, Japan held an isolationist policy; concepts of Western origin, such as rights and liberties, had no 
chance of penetrating society. When Japan opened its borders to the West, these concepts streamed quickly into society. The works of Samuel Smiles, John Stuart Mill, Jean-Jacques Rousseau, and Jeremy Bentham were translated and read by enthusiastic intellectuals of the Meiji era (1868 to 1912). In particular a translation of Herbert Spencer's Social Statics influenced intellectuals and government officials (Ogawa, 2008).

One of the most influential Japanese intellectuals of the Meiji period was Yukichi Fukuzawa, who introduced a translated version of the United States Declaration of Independence in his first edition of Seiyou Jijyou [the Western Affairs] (1866) to the Japanese public (Ogawa, 2008). Beginning with the famous phrase 'It is said that heaven does not create human beings above human beings, nor does it create human beings below human beings', Fukuzawa's Gakumon no Susume [An Encouragement of Learning] (1872 to 1876) was clearly influenced by the United States Declaration of Independence. Fukuzawa advocated that all human beings were born equal; how much the person learned differentiated them. He stressed the importance of freedom, equality, and a spirit of independence. The works of Fukuzawa were read widely among Japanese people of the Meiji era. Gakumon no Susume was read at least in part by one out of every 160 people in the 1870 s (Walker, 1979), and several million copies of his writings were sold between 1860 and 1890 (Gordon, 2003).

As Fukuzawa admits, intellectuals of the Meiji era who introduced new, Western ideas into Japanese society faced enormous challenges finding suitable terms to express new concepts (Yanabu, 1982). Some terms were created, while others were taken from Chinese translations of Western thought. This was possible because Japanese writing largely uses Chinese characters. The Japanese word for rights, for 
example, was taken from the Chinese translation of Henry Wheaton's Elements of International Law (1836), translated from English to Chinese in 1850 by American missionary, William Martin. In combination with Seiyo Jijou by Fukuzawa, the Chinese translation of Wheaton's book was one of the two best sellers of the era (Maruyama \& Kato, 1998). The Japanese translation of Elements of International Law was also published in 1870. While this represents the origin of the Japanese word for 'rights', the first time the phrase 'human rights' appeared in Japanese writing was in 1868 in Taiseikoku houron [The Legal Theory of the Western Countries] (Ogawa, 2008).

Japanese translation of the word 'right', however, carried with it the possibility of causing misunderstanding of the concept. Whereas kenri is the word used for the translation, ken carries the meaning of power or authority, and ri means profit. Thus, the Japanese word for 'right' indicates 'profit of authority'. Intellectuals were aware of the dangers of misunderstanding this translation could cause and tried to replace the term. Nevertheless, kenri settled as the translation (Yanabu, 1982). ${ }^{1}$

\section{Human rights movement under pre-war Japanese government}

The fact that the word minken (people's rights) was used for the human rights movement contributed to the confusion. In the late 1870 s, some intellectuals led a movement for the enhancement of liberty and human rights against government power. The movement was called jiyu minkin undo (the Movement for Freedom and People's Rights), and reached its height in the early 1880s. Using the word minken (people's rights) for human rights created the danger of human rights being 'understood as the right of a group of people who were fighting against the Meiji oligarchy rather than the rights of individuals' (Ishida, 1983, p. 71). The ease of 
connecting right with power and human rights with people's rights worked in favour of the authority of the Meiji government when it perceived a threat from the feverish movement for freedom and people's rights. By relating human rights with 'a collectivity rather than individuals', the government absorbed the human rights movement of minken (people's rights) into 'the advocates of kokken (a state's right vis-à-vis foreign powers)' (p. 72), enriching and strengthening the nation militarily to protect it from increasing imperialist activity by Western nations in the 1880s and 1890s. This absorption of the human rights movement into the state's rights movement was justified with the argument for a strong state that could compete with Western powers to enhance people's welfare (Ishida, 1983).

Thereafter, the sanctity of the emperor was emphasised, and rights were offered to the people as mercy under the condition that they fulfil their duty and, most importantly, they worship the emperor as a living god. The Constitution of the Empire of Japan (1889) declared in its preamble to 'respect and protect the security of the rights and of the property of Our people, and to secure to them the complete enjoyment of the same, within the extent of the provisions of the present Constitution and of the law'. The constitution guaranteed freedom of religious belief (Article 28) and the liberty of speech, writing, publication, public meetings and associations (Article 29), but such freedom was given only as long as it 'shall not affect the exercises of the powers appertaining to the Emperor, in times of war or in cases of a national emergency' (Article 31).

Since the people never came to fully understand human rights as inalienable individual rights, the idea that people ought to be protected and given certain rights by the emperor when they fulfil duties as his subjects was accepted without difficulty, and absorbed the movement for human rights. Even Fukuzawa, who introduced 
inalienable rights, eventually advocated the necessity of building a strong Japan with the emperor to compete with Western imperialism after 1880. By the mid-1890s, enthusiasm for the human rights of the 1880s had been swallowed up by the fervour to build 'a militarily strong, imperialist Japan' (Walker, 1979, p. 25).

To promote further the policy of building a strong nation with emphasis on the sanctity of the emperor, the Japanese government took up the tradition of familism and transformed it into the family-state ideology. Under this ideology, Japanese people were encouraged to identify themselves as members of the family-state, and to exhibit deep appreciation of emperor's patriarchal mercy. To root this ideology, the government promoted Confucian virtues of loyalty, obedience, and filial piety into moral education in schools. Moral education was the most important subject of elementary school education, established by the Imperial Rescript on Education promulgated in the name of the emperor in 1890 (Kawashima, 2000). The Rescript begins by glorifying imperial ancestors and emphasising national unity. It stresses a filial relationship with one's parents and the maintenance of harmony with people. It teaches children to offer themselves courageously to the state should an emergency arise, to protect 'the prosperity of Our Imperial Throne'. This Rescript was held sacred and enshrined as the spiritual pillar of education and national morality. As the enrolment rate at elementary schools in Japan reached nearly 100 percent by the end of the 1920s, moral education provided a firm foundation for patriotism and national conformity, and contributed to the creation of imperial Japan as a single family. This was further enhanced as the nation entered the Second World War.

\section{The sudden guarantee of human rights in post-war Japan}


Defeat of the nation in 1945 dramatically changed the situation. A sudden overturn of the family-state ideology occurred when the Japanese government signed the Potsdam Declaration at its surrender to the Allied Nations. The Declaration stated 'The Japanese Government shall remove all obstacles to the revival and strengthening of democratic tendencies among the Japanese people. Freedom of speech, of religion, and of thought, as well as respect for the fundamental human rights shall be established' (Article 10). The Constitution of Japan was created by the occupation authorities in 1946 and enacted the following year. Thereafter, 'enjoyment' of 'fundamental human rights' was guaranteed to the people 'as eternal and inviolable rights' (Article 11). The Constitution acknowledged fundamental human rights 'guaranteed to the people of Japan' as 'fruits of the age-old struggle of man to be free' that 'have survived the many exacting tests for durability' and are 'to be held for all time inviolate' (Article 97). These words suggest that human rights guaranteed to the Japanese people represent the concept people in the West fought for and won after centuries of struggle. In contrast, Japan's democratisation was suddenly given to the people with guaranteed human rights.

Sudden provision of human rights, however, does not automatically lead to people understanding the concept and becoming motivated to protect themselves by claiming inalienable rights. A survey conducted by the Ministry of Law a few years after the promulgation of the new Constitution in 1947 suggested that 30 percent of Japan's population had never heard of the term human rights (Ogawa, 2008). For human rights to begin functioning, dissemination of the concept accompanied by attitudinal changes in the people had to be achieved; this was the role of human rights education. However, human rights education was not a part of Japanese school curricula until the mid-1990s, while moral education, inheriting certain elements from 
the earlier model, such as the importance of harmony, human relationships, and obligation, continued to be in the mainstream of Japanese school education.

\section{Validity of human rights education in Japan}

Before the examination of human rights education in contemporary Japanese schools, a question of validity needs addressing: why should human rights, a Western concept, be taught to Japanese children? Several authors argue that although it is inappropriate to assume human rights are superior to other normative systems, the experience of the West suggests that human rights are the best existing candidate to safeguard dignified living in a modern society with capitalist economies (Donnelly, 1989). Panikkar (1982, p. 101) maintains that although introducing human rights before modernisation is meaningless and can be criticised as cultural imperialism, 'a technological civilization without Human Rights amounts to the most inhuman situation imaginable'. Stammers (1999) points out that people may not have needed human rights in the past, but that modernisation necessitates their application beyond cultural boundaries.

Oonuma (1998) argues that it is unforgivable to adopt a modern nation-state system and reject human rights; doing so condemns individuals - who used to enjoy security from traditional communal mechanisms - to live without protection against abuses of enormous state power. As Freeman (1995, p. 15) suggests, the question is not whether human rights fit into local cultural traditions, but 'whether it is useful and morally acceptable now'. As long as there are traditional societies, human rights will not gain complete universality. Nevertheless, contemporary, worldwide modernisation with the growth of global capitalist economies provides for the wider applicability of 
human rights, including in Japan, one of the first non-Western countries to modernise fully.

\section{The Japanese government's policies and guidelines for human rights education}

Emerging in mainstream government policy in the mid-1990s in response to the UN Decade, human rights education is relatively new to Japanese schools. In 1995, the government created the Head Office for the Promotion of the UN Decade for Human Rights Education within the Cabinet. The following year it enacted Jinken Yougo Suishin Hou [the Law for the Promotion of Human Rights Protection] ${ }^{2}$, charging the national government with the responsibility to promote human rights education.

In 1997, the Head Office created the Domestic Action Plan for the UN Decade for Human Rights Education (Jinken kyouiku notameno kokuren 10nen suishin honbu, 1997). The Plan argues that human rights education should be based on the Japanese Constitution, International Human Rights Statutes, and the Convention on the Rights of the Child (1989). It designates nine human rights issues to be addressed in Japanese human rights education relating to women, children, the aged, people with disabilities, social integration, people of the Ainu (an ethnic group indigenous to the northern part of Japan), foreigners, people infected with HIV (and the (ex-)patients of Hansen's disease) and ex-prisoners. Every document prepared by the government concerning human rights education treats these as the core issues of human rights education and advocacy.

Among the listed issues, social integration requires further explanation. In the Edo era (1603 to 1867), Japan was ruled by an official caste system, forcing the lower classes to live in segregated settlements. Although the system was abolished in 1871, the people who belonged to the lower castes/classes and their descendents continued 
to suffer from social discrimination, especially in employment and marriage. The Japanese government addressed the issue by passing the Special Measures Law for Assimilation Projects in 1969, and made funding available for various projects focused on eliminating social segregation and discrimination. The provision of integration education for the elimination of discrimination against the descendents of the outcaste class was part of the projects, and was included in Japanese elementary and secondary school moral education. With a consensus that these projects had resulted in certain improvements, assimilation projects were terminated in 2002. Prior to termination, the Cabinet determined in 1996 that integration education was to be reconstructed and promoted as part of human rights education and advocacy (Jinken yougo suishin shingikai, 1999). Consequently, human rights education in Japan took over integration education.

Another significant milestone in the Japanese government's policy to disseminate human rights education was a report prepared by Jinken yougo suishin shingikai (the Council for Human Rights Protection and Promotion) ${ }^{3}$ on human rights education and advocacy (the Council Report) in 1999. The report argues that human rights are to be respected not only in relation to public authorities, but also in relations amongst citizens. It concludes that in Japanese society henceforward, each citizen must possess an accurate understanding not only of his/her own rights, but the rights of others, and be aware of the responsibilities that accompany the exercise of rights, respect other's rights, and live well together.

In 2004, 2006, and 2008, a committee organised by the Ministry of Education produced reports (the Committee Reports) on the method of instruction for human rights education called the 'Ideal Guidance Methods for Human Rights Education' (Jinken kyouikuno shidouhouhoutou nikansuru chousa kenkyu kaigi, 2004; 2006; 
2008). They emphasise teaching compassion in human rights education, and refer to the development of learners' abilities to respect group rules, fulfil obligations and duties, and take actions to resolve issues when faced with human rights problems. Through human rights education, learners should develop the ability to (1) imagine and compassionately understand others, their needs, opinions, and feelings; (2) communicate to understand each other; and (3) develop good human relationships. Emphasis is thus on harmonious human relationships. These guidelines and the points to which the Council and Committee Reports refer are especially significant in studying Japanese human rights education; they are strongly reflected in the contents of human rights education in Japanese elementary and secondary schools, and therefore identify the features of Japanese human rights education.

\section{Human rights education characteristics in Japanese schools}

When human rights education was introduced into the curriculum of Japanese schools in the mid-1990s, it absorbed elements from two educational branches. One was integration education, mentioned in the previous section, and the other was moral education, part of Japanese education since the beginning of modern education in the late $19^{\text {th }}$ century. Moral education in the pre-war era taught children about Confucian virtues of loyalty, obedience, filial piety, and harmonious human relationships, with special emphasis on loyalty to the emperor. Although the post-war, fundamental reform of Japanese education altered the contents of moral education, some elements such as the emphasis on harmony and human relationships remained. Moral education promoted development of the sense of responsibility in society, and the ability to maintain harmonious relationships. 
The first two Committee Reports recommended integrating what had been moral education into the newly-developed human rights education. As relevant elements for human rights education, the reports highlight the following learning outcomes from the government guidelines on moral education: (1) appreciation for preciousness of human lives; (2) compliance with law and rules, valuing rights, fulfilling obligations, and making efforts to enhance social order and discipline; and (3) contribution to the realisation of a society without discrimination or prejudice. Japanese human rights education inherited these elements from moral education and, combined with integration education, focuses on issues of discrimination, obligations, and human relationships. Accordingly, notions such as kindness and compassion are emphasised in combination with the importance of fulfilling obligations.

Teaching the significance of harmonious human relationships and fulfilment of obligations is certainly important in human rights education, as mentioned in UNESCO’s Recommendation concerning Education for International Understanding, Co-operation and Peace and Education relating to Human Rights and Fundamental Freedoms, adopted by the UN in 1974. The Recommendation, which marked a milestone in international education (Ikuta, 2007), includes 'awareness not only of the rights but also of the duties incumbent upon individuals, social groups and nations towards each other' in its 'major guiding principles of educational policy'.

However, one question is whether a balanced approach is taken when observed from a broader perspective or when viewing human rights education in its entirety. As mentioned earlier, the UN Action Plan recommends 'a comprehensive approach' with 'the imparting of knowledge and skills and the moulding of attitudes'. Prior to the Action Plan, a similar stance was taken in Guidelines and Criteria for the Development, Evaluation and Revision of Curricula, Textbooks and other Educational 
Materials in International Education in Order to Promote an International Dimension in Education (1991), of which UNESCO led the formation. The Guidelines and Criteria advocates four dimensions (knowledge, attitudes, values and skills) as being necessary to promote principles - including human rights - comprehensively. Along with the elements inherited from moral education, Japanese human rights education needs to impart human rights knowledge and encourage attitudinal change in learners, so that they become empowered with rights-claiming behaviours. For a further discussion of this balanced or comprehensive approach to human rights education, citizenship education in England presents a suitable case for comparison.

\section{Citizenship education in England as a comparison case}

In the English National Curriculum, human rights education is an integrated part of citizenship education, provided to all students aged 11 to 16 in maintained schools as a statutory subject since 2002. Introduction of citizenship education followed the recommendations of the Crick Report of 1998. According to the Report (Qualifications and Curriculum Authority, 1998), the purpose of citizenship education is 'to enhance the awareness of rights and duties, and the sense of responsibilities needed for the development of pupils into active citizens'. As found in Japanese human rights education, duties and responsibilities are regarded as important elements of citizenship education in England. Nevertheless, English citizenship education also places emphases on knowledge, skills and the moulding of attitudes, suggesting congruence with the comprehensive approach advocated by the UN Action Plan. The Crick Report refers to securing and increasing the 'knowledge, skills and values' relevant to 'participatory democracy' as the purpose of citizenship education, and sets 'active citizenship' as the 'aim throughout'. 
Concepts (including human rights, rights and responsibilities); values and dispositions; skills and aptitudes (including concern for human rights); and knowledge and understanding (including human rights charters and issues) are the four essential elements the Crick Report advocates. The report emphasises the significance of the 'successful integration and progressive development' of these essential elements and points out the benefit of citizenship education as 'an entitlement' that will 'empower' the students 'to participate in society effectively as active, informed, critical and responsible citizens'.

A longitudinal study (2001 to 2009) of the impact of citizenship education by the National Foundation for Education (Department for Education, 2010) reports that cohorts receiving many hours of citizenship education are more likely to hold positive attitudes toward civic and political participation. Participation in political activities such as signing petitions, and civic activities such as fund-raising for charities and good causes, are found to increase over time. It reports cohorts becoming 'markedly more supportive about human rights and women's rights'. Though the impact of citizenship education is still debated and awaits further investigations, the report suggests that citizenship education in England moulds children's attitudes through imparting knowledge and skills.

\section{Factors emphasised less in Japanese human rights education}

The Crick Report cites Lord Chancellor's words that citizenship education 'must give people confidence to claim their rights and challenge the status quo while, at the same time, make plain that with rights come obligations'. Although Japanese human rights education emphasises the significance of obligation, the same is not necessarily true of other factors, such as imparting knowledge and skills and moulding attitudes. 
Compared to the emphasis placed on responsibility and obligation, Japanese human rights education does not place similar emphasis on imparting knowledge, or more specifically, intellectual and legal knowledge concerning human rights (Ikuta, 2007). This is despite the fact that the importance of imparting fundamental understanding and comprehensive knowledge (both intellectual and legal) of human rights is highlighted in many government guidelines. The consequent lack of understanding amongst Japanese people about their guaranteed rights is observed in the result of a survey conducted by NHK (the Japanese national broadcasting company) (NHK Housou Bunka Kenkyusho, 2000, pp. 90-92). When asked, 'Which of the following are guaranteed not as duties but as rights in the Constitution?', subjects chose public expression of opinion (37\%, down from 49\% in 1973), paying taxes (42\%, up from 34\% in 1973), obeying one's superiors (7\%), walking on the right side of the road (16\%), leading a humane life (76\%) and organising a trade union (23\%, down from 39\% in 1973). Many people confused duties with rights, and whereas many people recognised some social and economic rights as guaranteed rights, there was common lack of knowledge about civil and political rights.

The Council Report refers to low human rights knowledge: 'It has been pointed out that due to the lack of understanding of one's own possessed rights, people sometimes do not fully claim their rights when they rightfully ought to claim them'. Significant is the suggestion that lack of knowledge results in lack of action taken by people to protect their rights. Cohrs et al. (2007, p.459) support this argument that connects human rights knowledge and behaviour; they found 'People who in general endorsed human rights more strongly and who were able to name concrete human rights were more likely to report being engaged in human rights behavior'. 
Moreover, the strong emphasis placed on obligation, responsibility and harmonious human relationships in Japanese human rights education may impede the moulding of attitudes to protect human rights by claiming them. For human rights to be effective protection of people's human dignity, people must claim them freely in the face of other individuals, groups or organisations in society or the state. To protect him/herself using human rights, 'people not only may, but ought to, insist' on them. It is 'only because rights may lead to demands and not something weaker that having rights is tied as closely as it is to human dignity' (Shue, 1980, p. 14). Having rights enables a person to press individual demands. Empowering learners, by enabling them to insist on rights in cases where human rights are violated, should be one of the primary goals of human rights education. This is described as 'the moulding of attitudes' in the UN Action Plan. The Japanese government's guidelines also mention the importance of developing learners' abilities to act when faced by human rights issues (e.g., the Committee Reports of 2004, 2006, and especially 2008).

Nevertheless, strong emphasis on the maintenance of harmonious human relationships, in combination with a lack of imparting human rights knowledge, reinforces the collectivistic norm prevalent in Japanese society that one has to consider the inconvenience it causes before taking action, even when claiming one's rights. In collectivistic cultures, where the maintenance of social harmony occupies the top priority, the social norms tend to restrict claims by individuals for their rights. Consequently, while the norms of Japanese people's behaviour are formed by duties and obligations, individualistic ideas of human rights may face enormous difficulties in being accepted in society. The following survey results clearly indicate the existence of intolerance among Japanese people toward other people's claiming their rights. 
Conducted in 2007 by the Ministry of Justice and the Ministry of Education (2008), results of a national survey on Japanese people's awareness revealed that $85.2 \%$ of 3,000 Japanese who took part thought that an increasing number of people were claiming their rights without considering the nuisance such behaviour causes others. This result carries a comment by the Ministries: 'The percentage of people agreeing with the statement has increased from $76.7 \%$ in the last survey [2003] to 85.2\%. This indicates that there is not enough prevalence amongst the citizens of the awareness that when claiming their own rights, one also needs to fully consider the rights of others'. If 'it is essential to a right that it is a demand upon others' (Shue, 1980, p. 16), however, it is inevitable that the demand causes some inconvenience to the party the demand is made against. If society requires a person to cause no inconvenience to anybody when demanding his/her rights, there can be no rights claim in that society, even when people's rights are violated.

With strong emphasis on obligation and harmonious human relationships and less emphasis on imparting human rights knowledge, the approach to human rights education in Japan creates obstacles to the function of human rights in society as a protection of human dignity. As Hugh Starkey (cited in Brown, 1996, p. 8) points out, 'Human Rights are only rights when people know about them and can therefore exercise them'. A consequent lack of formation of human rights attitudes and behaviour means that while human rights education during the UN Decade was to 'affect positively' the learners' 'attitudes and behaviour', this aspect is missing in Japanese human rights education. Such education needs to place more emphasis on empowerment, a crucial element of human rights education. According to Amnesty International, 'Human rights education is about empowering tomorrow's citizens. 
Schools have an important role to play in contributing to that empowerment...' (Brown, 1996, p. 9).

It is important to acknowledge that emphasis on the values of obligation, responsibility and harmonious human relationships placed in Japanese human rights education is congruent with historically cultivated behavioural norms in Japanese society. As early as in $604 \mathrm{AD}$, Shotoku Taishi (the regent of the country) enacted Junanajou no Kempou (Seventeen Article Constitution), with its first article stating: 'Harmony is to be valued, and an avoidance of wanton opposition to be honoured'. Since then, for over 1400 years, social morality in Japan has always emphasised the social harmony. The emphasis on the values of obligation and responsibility placed in Japanese human rights education should therefore be valued as part of long cherished social virtue in the collectivistic society. The continued emphasis placed on compassion and kindness in Japanese school education is to be appreciated. However, Japanese human rights education also needs to address learner empowerment by imparting comprehensive human rights knowledge and skills, and moulding attitudes, as the UN Action Plan sets out as the task of human rights education in the UN Decade.

\section{Conclusion}

Using accounts of development of the human rights concept in the West and in Japan, this paper has examined the characteristics of Japanese human rights education, emerging in the mid-1990s in reaction to the UN Decade. The characteristics of Japanese human rights education in the classroom are found to place strong emphasis on duty and obligation, accompanying others' rights, but less on imparting human rights knowledge. These characteristics create obstacles to moulding human rights 
attitudes, resulting in a lack of empowerment by disallowing learners from claiming their rights. While the UN Action Plan identifies the necessity of a comprehensive approach to human rights education, this investigation suggests that attention is imbalanced in Japanese human rights education.

Building on the achievement of the UN Decade, the World Programme for Human Rights Education was launched in 2005, with its first phase (2005 to 2009) focusing on human rights education in primary and secondary schools. The plan of action for the first phase (University of Minnesota Human Rights Library, 2005) emphasises a balanced, comprehensive approach, advocated in relation to the UN Decade. It refers to the methods and approaches that empower learners, so they can put human rights into practice. It advocates that for the achievement of quality human rights teaching and learning, it is necessary to 'give equal importance to cognitive (knowledge and skills) and social/affective (values, attitudes, behaviours) learning outcomes'. The plan is based on the definition of human rights education as education 'aiming at building a universal culture of human rights'. It aims to share best practices and create a common culture of human rights.

At the same time, the plan recognises that the context surrounding human rights education differs from country to country, and suggests ensuring 'that human rights education materials stem from the human rights principles as embedded in the relevant cultural contexts as well as historical and social developments'. This acknowledges the challenges faced by Japanese society in the dissemination of the concept of human rights, started as 'human rights given to the people by the nation' in opposition to the Western concept of 'human rights given by heaven' (Higuchi, 1996). A strong emphasis on obligation placed in the moral education of pre-war Japan is an 
important historical development, inherited by the moral education of post-war Japan and current human rights education.

However, this does not change that Japanese human rights education must improve its efficacy as a tool of learner empowerment. Above all, Japanese human rights education needs to adopt a more comprehensive approach. Since all dimensions are correlated, placing much stronger emphasis on some dimensions of human rights over others results in ineffective human rights education. To contribute to learner empowerment and create tomorrow's citizens who can use human rights as an instrument of self-protection when rights are violated, Japanese schools must move towards applying a balanced human rights education approach with equal emphases on each dimension.

\section{Notes}

1. When the term 'right' first appeared to Japanese intellectuals, it appeared as a legal term in international law being used 'in connection with the rights of a state in international relations and only rarely applied to the rights of individuals' (Ishida, 1983, p. 71). The connotation of authority profit was, in that case, not far from the original meaning of right.

2. The law expired in 2002; prior to expiration, the government enacted another law, the Law Concerning the Promotion of Human Rights and Human Advocacy, in 2000 and reinforced the responsibility of the government to set the policy for human rights education and its implementation.

3. Following stipulation of the law of 1996, the Council was established in the Ministry of Justice to promote human rights education and advocacy amongst Japanese citizens.

\section{References}

An-Na'im, A.A. (1990). Islam, Islamic law and the dilemma of cultural legitimacy for universal human rights. In C.E. Welch, Jr. \& V.A. Leary (Eds.), Asian perspectives on human rights (31-54). Boulder: Westview Press.

Brown, M. (Ed.). (1996). Our world, our rights: Teaching about rights and responsibilities in the primary school. London: Amnesty International.

Cohrs, J.C., Maes, J., Moschner, B., \& Kielmann, S. (2007). Determinants of human rights, attitudes and behaviours: A comparison and integration of psychological perspectives. Political Psychology, 28(4), 441-469. 
Department for Education. (2010). Citizenship education in England 2001-2010: Young people's practices and prospects for the future: The eighth and final report from the Citizenship Education Longitudinal Study (CELS). Retrieved July 28, 2011, from https://www.education.gov.uk/publications/eOrderingDownload/DFERR059.pdf

Donnelly, J. (1989). Universal human rights in theory and practice. Ithaca: Cornell University Press.

Freeman, M. (1995). Human rights: Asia and the West. In J.T.H. Tang (Ed.), Human rights and international relations in the Asia-Pacific region (13-24). London: Pinter.

Gordon, A. (2003). A Modern history of Japan: From Tokugawa times to the present. New York: Oxford University Press.

Higuchi, Y. (1996). Jinken [Human rights]. Tokyo: Sanshoudou.

Hunt, L. (Ed.). (1996). The French Revolution and human rights: A brief documentary history. Trans. and intro. Hunt. Boston: Bedford Books of St. Martin's Press.

Ikuta, S. (2007). Jinken to kyouiku: Jinken kyouikuno kokusaiteki doukouto nihonteki seikaku[Human rights and education: The international trends of human rights education and Japanese characteristics]. Kyoto: Burakumondai kenkyusho.

Ishida, T. (1983). Japanese political culture: Change and continuity. New Brunswick: Transaction Books.

Jinken kyouikuno shidouhouhoutou nikansuru chousa kenkyu kaigi [The Research and Investigation Council on Human Rights Education's Methods of Instruction]. (2004). Daiichiji torimatome [The first report]. Retrieved July 5, 2009, from http://www.mext.go.jp/b_menu/shingi/chousa/shotou/024/report/04062501.pdf

Jinken kyouikuno shidouhouhoutou nikansuru chousa kenkyu kaigi [The Research and Investigation Council on Human Rights Education's Methods of Instruction]. (2006). Dainiji torimatome [The second report]. Retrived July 5, 2009, from http://www.mext.go.jp/b_menu/shingi/chousa/shotou/024/report/06012408/001.pd $\mathrm{f}$

Jinken kyouikuno shidouhouhoutou nikansuru chousa kenkyu kaigi [The Research and Investigation Council on Human Rights Education's Methods of Instruction]. (2008). Daisanji torimatome [The third report]. Retrieved July 5, 2009, from http://www.edu.pref.ibaraki.jp/board/gakkou/jinken/image/sidou-dais annji.pdf

Jinken kyouiku notameno kokuren 10nen suishin honbu [The Head Office for the Promotion of the UN Decade for Human Rights Education]. (1997). 'Jinken kyouiku notameno kokuren 10nen' nikansuru kokunai koudoukeikau [The domestic action plan for 'the UN Decade for Human Rights Education']. Retrived June 15, 2009, from http://www.kantei.go.jp/jp/singi/jinken/kettei/970704keikaku.html 
Jinken yougo suishin shingikai [The Council for Human Rights Protection and Promotion]. (1999). Toushin [Report]. Retrieved June 17, 2009, from http://www.mext.go.jp/b_menu/gyouji/1999/990801.htm

Kawashima, T. (2000). Nihon shakai no kazokutekikousei [The family-like structure of Japanese society]. Tokyo: Iwanami-shoten.

Maruyama, M., \& Kato, S. (1998). Honyakuto nihonno kindai [Translation and Japan's modern times]. Tokyo: Iwanami-shoten.

Ministry of Justice and Ministry of Education, Culture, Sports, Science and Technology (Eds.). (2008). Jinken kyouiku•keihatsu hakusho [White paper on human rights education • advocacy]. Tokyo: Saeki Insatsu Ltd.

NHK Housou Bunka Kenkyusho (Ed.). (2000). Gendai nihon-jin no ishiki kouzou [The structure of contemporary Japanese people's consciousness]. Tokyo: Nihon Housou Shuppan Kyoukai.

Ogawa, M. (2008). Jinkenno hajimari: Kindai nipponno jinken shisou [The beginning of human rights: Human rights thoughts of modern Japan]. Tokyo: Burakumondai Kenkyusho.

Oonuma, Y. (1998). Jinken, kokka, bunmei: Fuhenshugiteki jinkenkan kara bunsaiteki jinkenkan he [Human rights, nation-state, and civilisation: From universal human rights to intercivilisational human rights]. Tokyo: Chikuma-shobou.

Panikkar, R. (1982). Is the notion of human rights a Western concept? Diogenes. CXX, 75-102.

Stammers, N. (1999). Social movements and the social construction of human rights. Human Rights Quarterly, 21, 980-1008.

Qualifications and Curriculum Authority. (1998). Education for citizenship and the teaching of democracy in schools: Final report of the Advocacy Group on Citizenship. Retrieved July 28, 2011, from http://www.teachingcitizenship.org.uk/dnloads/crickreport1998.pdf

Shue, H. (1980). Basic rights: Subsistence, affluence, and US foreign policy. Princeton: Princeton University Press.

United Nations. (1994). Plan of Action for the United Nations Decade for Human Rights Education, 1995-2004: Human rights education - lessons for life. Retrieved June 10, 2009, from http://daccessdds.un.org/doc/UNDOC/GEN/N97/008/02/PDF/N9700802.pdf?Ope nElement

University of Minnesota Human Rights Library. (2005). World Programme for Human Rights Education: Plan of action for the first phase (2005-2007).

Retrieved August 10, 2011, from http:/www1.umn.edu/humanrts/instree/worldprogramme.htm 
Walker, J.A. (1979). The Japanese novel of the Meiji period and the ideal of individualism. Princeton: Princeton University Press.

Yanabu, A. (1982). Honyakugo seiritsu jijou [Formation of terms' translation]. Tokyo: Iwanami-shoten. 